Article

\title{
Art Galleries in Transformation: Is COVID-19 Driving Digitisation?
}

\author{
Beatrix E. M. Habelsberger and Pawan V. Bhansing *
}

Citation: Habelsberger, Beatrix E. M., and Pawan V. Bhansing. 2021. Art Galleries in Transformation: Is COVID-19 Driving Digitisation? Arts 10: 48. https://doi.org/10.3390/ arts10030048

Academic Editor: Elena Sidorova

Received: 31 May 2021

Accepted: 13 July 2021

Published: 23 July 2021

Publisher's Note: MDPI stays neutral with regard to jurisdictional claims in published maps and institutional affiliations.

Copyright: (c) 2021 by the authors. Licensee MDPI, Basel, Switzerland. This article is an open access article distributed under the terms and conditions of the Creative Commons Attribution (CC BY) license (https:/ / creativecommons.org/licenses/by/ $4.0 /)$.
Department of Media \& Communication, Erasmus School of History, Culture and Communication, Erasmus University Rotterdam, 3000 DR Rotterdam, The Netherlands; habelsberger@outlook.com

* Correspondence: bhansing@eshcc.eur.nl

\begin{abstract}
Compared to other consumer goods markets, art galleries have long been reluctant to innovate through digitisation. However, the global outbreak of COVID-19 forces art galleries to reconsider the role of digital channels. This study aims to provide a better understanding of the art gallery business model and its related difficulties of integrating digital channels into marketing, communication, and sales. Twenty interviews with gallery owners and managers in Vienna and Salzburg were conducted. They were asked about their attitudes towards, opinions on, and experiences with digital channels, and how they reacted to the restrictions caused by COVID-19. The findings verify that COVID-19 has led galleries of any type to reconsider their digital strategy. We identified limitations with respect to digital channels: plain presentation of information online; lacking or distanced personal interaction; online anonymity that disconnects from the social art environment; increased information and price transparency; a more commercial appearance; limited resources for digital adaptations. Galleries striving to integrate digital channels into their business model should pay attention to ensuring that analogue, as well as digital, channels are integrated into a coherent system where personal contact and the physical location remain the core of the business.
\end{abstract}

Keywords: art galleries; art market; digital technology; multi-channel strategy; business model innovation

\section{Introduction}

The gallery business is strongly based on personal contact and social interaction between gallery and buyer, and is mainly focused on physical locations, such as the gallery space and art fairs (Arora and Vermeylen 2013; Smith et al. 2006). In general, the art market is characterised as relatively exclusive and intransparent, which means that information such as prices and the entire sales process are usually treated as private and confidential (Adam 2014). However, this way of conducting business has been challenged by the increasingly readily available information on the Internet and the opportunities that new digital communication technologies offer. Digital channels enable collectors and buyers to make more informed buying decisions (Arora and Vermeylen 2013; McAndrew 2015; Samdanis 2016). They facilitate worldwide networking and communication, enable transactions and acquisitions at a distance, and thereby provide the basis for new business opportunities on the art market (Samdanis 2016). Moreover, they allow galleries to reach new markets and to connect these markets more effectively (Adam 2014; Arora and Vermeylen 2013; Khaire 2015). In general, the Internet has facilitated global visibility of art market participants, making it easier for buyers and collectors to access a broader range of offerings on a global level. This may transform the traditional gallery business model.

In recent years, numerous new digital business concepts and platforms have emerged within the art market that also offer new opportunities for galleries. Websites such as

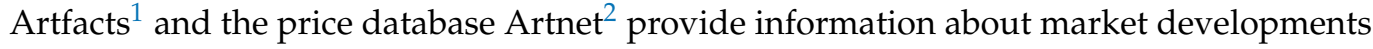
of artists (Bayer 2018; Sidorova 2019; Velthuis 2014). Intermediary sales platforms, such as Artsy $^{3}$ and Saatchi Art ${ }^{4}$ enable art galleries and artists to offer artworks for sale, similar 
to common online shops (Sidorova 2019). Auction houses are hosting online auctions, where people can bid from home, and art galleries have recently started creating virtual showrooms where artworks are displayed and offered for sale (Sidorova 2019). Despite these developments, many galleries are still using digital possibilities merely for creating their "digital business cards" (Arora and Vermeylen 2013; Kohle 2014; Samdanis 2016; Sidorova 2019), and have not considered fundamentally changing their business models by incorporating a digital strategy, and selling art online (Adam 2014; McAndrew 2015; Pownall 2017; Samdanis 2016; Van Miegroet et al. 2019). Considering that younger generations - the "digital natives" - are increasingly falling into the group of potential art buyers and that they have high expectations regarding immediacy and convenience through digital channels, this may be problematic for galleries.

The degree of galleries' digital technology adaption contrasts with developments in many industries (Arora and Vermeylen 2013; Kohle 2014; Samdanis 2016; Sidorova 2019), which have experienced a major transformation in their business model since the advent and proliferation of the Internet and digital communication technology (Teece 2010; Verhoef et al. 2015). These businesses found it necessary to take advantage of digital channels in order to interact with their various stakeholders and to preserve their prominence and market relevance (Ernst \& Young 2012). Many of them have considered a multi- or omnichannel approach, resulting in successfully and consistently integrated information on all online and offline channels (Kumar and Venkatesan 2005).

To date, there have been surprisingly few comprehensive studies on the subject of online art sales in the context of the gallery business. While there are several art market reports dedicated to the economic growth of online sales (e.g., McAndrew 2021; Pownall 2017), they do not address the topic from a social science perspective. Those researchers who addressed this topic have mostly done so in a broader research context or only described general developments (e.g., Adam 2014; Arora and Vermeylen 2013; Kohle 2014; Velthuis 2014). It has been argued that, for galleries, online sales would only be compatible with the lower price segment, while art in the higher price segment cannot be sold online (Adam 2014; Fassio 2019; Khaire 2015; Samdanis 2016). In addition, some researchers suggest that the power and role of galleries could be threatened by developments in digitisation. The transparent nature of online services implicates broad access to information, which in turn has made the formation of opinions and trends more democratic than ever before. Moreover, there is a fear that certain quality standards and the boundary between high- and low-quality art may become blurred (Arora and Vermeylen 2013; Van Miegroet et al. 2019). A more in-depth discussion on all these factors is yet to be prepared. Also, while there are countless research contributions on electronic commerce in the field of consumer goods (e.g., Gefen et al. 2003; Kassim and Abdullah 2008), these findings cannot easily be applied to the online sale of art due to the aforementioned characteristics of the art market and gallery business. Consequently, there is a gap in research on the topic of online sales in the gallery business.

The above-mentioned developments in digital innovation are gaining significance in light of the outbreak of the global COVID-19 pandemic, which has had a tremendous impact on the art market. For months, mobility was restricted for all art market participants, and events and art fairs worldwide were cancelled. As a result, art galleries, as well as other art market players, had to consider alternatives to their current strategies and activities to reach people during this period of restrictions (Gerlis 2020). This study aims to provide comprehensive insights from the perspective of gallery directors and managers on how they perceive the current impact of digital technology on their business, while particularly focusing on the impact of the pandemic. Moreover, this research provides insight into how galleries can best integrate digital channels into their business model. The research question investigated in this paper is "How are art galleries sustaining their businesses in times of digital business transformation and to what extent does the global COVID-19 pandemic play a role?" 
Our research is focused on art galleries in the Austrian cities Vienna and Salzburg. Both cities are well-known hotspots for art and culture, have a high density of art galleries, and offer a good balance between galleries with a more national focus and galleries with a strong international focus. This gives a comprehensive picture of the attitude of different kinds of galleries towards the topic of investigation. We categorise galleries in four types, based on parameters such as gallery size, scope, activity, and international significance: Alpha, Beta, Gamma, and Delta galleries (Resch 2011). Since this study covers the exploration of a topic on which there is relatively little pre-existing research, a qualitative approach based on in-depth interviews is the most appropriate. The owners, directors, and/or managers of 20 art galleries were interviewed. They are experts in their business area and are thus able to provide first-hand and in-depth information. The resulting data set was processed through a thematic analysis by coding the statements and identifying patterns and themes.

\section{Theoretical Framework}

\subsection{The Art Market and the Role of Galleries}

In general, the art market is segmented into the primary and the secondary market. On the primary market, artworks by contemporary artists enter the market for the first time, either in that the artist sells it directly to clients, or through a contemporary art gallery (McAndrew 2010; Velthuis 2011b). On the secondary market, art is re-sold, usually by auction houses or art dealers (Velthuis 2011b). In this paper, we define 'art gallery' as the umbrella term for both contemporary art galleries on the primary market and art dealers on the secondary market. Contemporary art galleries usually keep artworks of living artists they represent on consignment for the duration of an exhibition and, once an artwork is sold, the artist receives a pre-defined share of the sales price (Velthuis 2011a). Especially for younger artists entering the market, there is a great deal of uncertainty regarding their reputation, value, and market development (Beckert and Rössel 2004; Yogev 2009). Art dealers on the secondary market either take artworks from collectors on consignment or buy art and try to resell it at a profit (Velthuis 2011a). On the secondary market, usually more established art is sold, providing the buyer with greater certainty (Resch 2011; Zorloni 2013). In practice, both gallery forms can overlap, for example, in that art dealers can represent living artists or contemporary art galleries can sell artworks that they bought from a collector, and do not stem from the artist's studio.

The role of art galleries in the context of the market is manifold. They are important intermediaries committed to creating the symbolic and economic value of art (Bourdieu 1993; Velthuis 2014). Moreover, they are empowered to set an appropriate price level, to manage supply and demand (Caves 2000; McAndrew 2010; Velthuis 2014), and to build up trust in a fundamentally uncertain market (Velthuis 2007, 2011b). This is done by promoting the artists in the cultural networks and creating demand among potential buyers (Janssen and Verboord 2015). More specifically, galleries host events such as studio visits, opening parties, vernissages, or dinners for selected groups of people (Velthuis 2011a, 2014). Since value is not inherent to the artwork itself, but socially constructed, promotion activities are a way to raise the economic and symbolic value of artists and artworks (Polleit-Riechert 2010; Velthuis 2011a, 2011b). For customers, galleries function as art advisors when they support collectors with their buying decisions, inform them about new trends and emerging artists, and connect them with curators, artists, and other experts (Fillitz 2014). By building personal relationships with collectors, trust in the gallery and quality of the artworks is generated, while also creating the feeling of belonging to an exclusive community (Janssen and Verboord 2015; Velthuis 2014). Having a strong network in the art world is an essential part of the gallery business (Velthuis 2011a). If galleries manage these processes well over some years, they may establish a good and reliable reputation and will be in high demand by collectors and artists alike (Polleit-Riechert 2010; Throsby 1994).

In general, galleries focus their business models on buyers that have particular motives and disposable income. There are multiple motives for buying art: for decorative purposes; 
in order to gain social attributes; to belong to a social elite and to distinguish oneself from others; for aesthetic pleasure and the passion for art, which is especially true for art collectors and connoisseurs; and the motive of financial investment, whereby economic criteria of artworks are central. This usually applies to the higher price segment (Schultheis 2017; Velthuis 2007, 2011b; Zorloni 2013). As a general rule, galleries prefer to sell to art lovers and collectors, as the artworks usually remain in their possession for a long time. The reason for this is that when an artwork is owned by a renowned collector, the value of the artist and artwork usually increases. ${ }^{5}$ In contrast, if art is sold to investors who buy art for purely speculative reasons, art becomes a commodity. In this case, there is a risk that the financial value of the artwork could increase or decrease in an unpredictable way when the buyer offers it for sale on the secondary market shortly after acquiring it. This means that the artist's reputation and value could either sharply increase or decrease within a short period of time. Especially when a lower price is reached on the secondary market, doubts arise as to whether the earlier price was justified, leading to greater market uncertainty and buyers potentially avoiding a certain gallery or artists (Adam 2014; McAndrew 2010; Polleit-Riechert 2010; Zorloni 2013).

\subsection{Art Gallery Categories}

According to Throsby (1994), the art market can be divided into three levels. On the lowest level, small shops, local contemporary art galleries, and art dealers sell art of little artistic and monetary value. Here, art predominantly has a decorative character and there is generally excess supply (Knebel 2007; Throsby 1994). On the middle level, more established art galleries, art dealers, and artists sell art on a regional or national level. Usually, they are located in more or less important art hotspots and sell to both private collectors and public institutions (e.g., museums). The top level is formed by the international market, where the most renowned artists are traded at high prices. On this level, mainly wealthy private individuals but also companies, museums, and speculators buy art (Knebel 2007; Throsby 1994) via agents, such as international auction houses, art dealers, and galleries.

Similar to the three vertical levels defined by Throsby (1994), Resch (2011) distinguishes between four different types of galleries. ${ }^{6}$ The Alpha galleries operate on the top level of the art market. They are known worldwide, have a professional management structure, and have an exclusive group of the world's most important collectors as clients, as well as relationships with top museums. They sell art of the most sought-after artists with a high investment character and participate in the most important art fairs, such as the TEFAF or the Art Basel. Beta galleries have a slightly less professional management structure, are usually nationally known, and sell high quality art. There is slightly less potential for investment and the clients are typically national collectors and museums. They also participate in major international art fairs such as the Art Basel, but with a small booth, or in secondary fairs such as the Art Cologne. The Gamma galleries have a rather intuitive form of management and represent a combination of emerging and established artists that are not featured in the Alpha or Beta galleries. Unlike the Alpha and Beta galleries, they are not trendsetters and attend less renowned art fairs. They do not have a firm collector base, but rather have occasional buyers and do not cooperate with museums. Finally, there are Delta galleries, with an undeveloped management structure and no specific artistic orientation. In these galleries, there is no actual collector base and there are mostly occasional or one-off buyers. They mainly participate in smaller and often local art fairs (Resch 2011). While these four types of galleries are easy to distinguish from each other in theory, their categorisation is more ambiguous in practice. Therefore, in this paper, each gallery is assigned to one or two gallery types and additional information regarding the size of the gallery, scope of the client base and price segment is provided in order to obtain a better understanding of the characteristics of the gallery. Moreover, to align this typology more closely with reality and new opportunities arising from digitisation and globalisation, we add that even smaller Gamma and Delta galleries can have an international market orientation. 


\subsection{The Impact of Digital Technology on Art Galleries}

Among the various factors that have influenced the competitive landscape of businesses in recent years, the emergence and proliferation of information and communication technology (ICT) is one of the most significant. This is why it is often referred to as disruptive technology (Cortimiglia et al. 2013). Along with the introduction of digital media, a new generation, often referred to as "digital natives", has evolved. Digital natives were born after 1980, when digital technologies became widely available, and grew up with the access to and use of new digital communication tools (Ernst \& Young 2012). They have high expectations when it comes to the availability of information and the authentic and personal involvement of companies. Moreover, the population of digital natives is increasing in size, while the older generations are disappearing (Ernst \& Young 2012). These developments have a significant impact on businesses of any kind. First, with the digitisation and proliferation of digital channels, consumers have easy access to information and can compare prices and other information more easily. Second, digital channels have changed the communication of businesses from a traditional unidirectional to a bior multidirectional communication between customers and companies. Third, digital channels lead to lower entry barriers for competitors, which can pose a significant threat to traditional companies (Ernst \& Young 2012). These developments have contributed to an accelerated production, delivery, and consumption of goods and services, and have substantially affected all economic sectors (Sidorova 2019). The art market is not exempt from the growing importance of digital developments.

The increasing use of digital channels can help galleries in attaining new clients that would either be hard to approach due to geographical distance or would be afraid to enter the gallery. Consequently, it is believed to lead to an art market where not only an elite, but everyone, can get access (Adam 2014; Arora and Vermeylen 2013; Fassio 2019; Khaire 2015). However, more sensitive information, such as prices, is still rather unlikely to be found on the Internet (Van Miegroet et al. 2019). Especially in the upper market segment, galleries maintain an exclusive image, price tags are rarely found, and they often disclose information only on request (Fillitz 2014). From this, it can be concluded that digital channels have so far been regarded as additional channels that are not (yet) fundamentally changing the existing gallery business model (Van Miegroet et al. 2019).

Several assumptions disclose why galleries are rather sceptical when it comes to selling art online. The first assumption is that art galleries could fear losing their power in the valuation process of art and their role in the art market due to the democratic nature of the Internet. As outlined above, galleries are important gatekeepers that help to select and promote artists of good quality (Van Miegroet et al. 2019). This gives rise to the fear that the division between high and low quality could be blurred, and that their powerful gatekeeping roles could be weakened (Arora and Vermeylen 2013). ${ }^{7}$ Connected to this is the fact that galleries want to maintain an exclusive image by disclosing prices only upon request and granting access to information only through personal contact with the gallery staff (Fillitz 2014; Velthuis 2007). Furthermore, galleries could fear being perceived as too commercial if they were to offer artworks for sale online. This implies that galleries are afraid that online art sales could take on the character of supermarket shopping, thus turning artworks into commodities and losing the deeper artistic identity (Kohle 2014).

The social aspect and the importance of personal contact for the success of the gallery business are additional significant reasons for art galleries to not integrate online sales into their business model. As was explained above, the value creation of art is primarily based on personal contacts and professional networks (Samdanis 2016), which cannot be easily transferred to the online space. Still, the intensive discussions between experts, connoisseurs, and gallery owners, as well as the close support of artists and the physical gallery space, are essential for gallery operations, because it is thought to be the only way for galleries to build trust and reputation in the market (Kohle 2014; Smith et al. 2006). Moreover, many customers actually enjoy and prefer the personal contact with artists, gallery owners, and other art world members, as well as the experience of events which 
is not reproducible online (Arora and Vermeylen 2013). Finally, art galleries might be convinced that art needs to be experienced physically and that the Internet is not suitable for selling art. Art is an experiential good, which means the quality of artworks can best be assessed when seeing and experiencing it (Arora and Vermeylen 2013; Bayer 2018). This concept might also be prevalent among customers who take the risk of buying an artwork of poor quality if not being able to see it physically (Velthuis 2014).

Another aspect that could contribute to why galleries are not engaging more in digital channels is the lack of entrepreneurial thinking. It has been found in previous research that organisational skills, as well as financial knowledge and literacy, are often lacking in the cultural industries (de Graaf et al. 2019). This could be equally applicable to galleries, as Smith et al. (2006) state that galleries are usually not inclined to hire someone with entrepreneurial experience. Moreover, as most galleries are small enterprises and are therefore limited in their management resources, this could also explain why art galleries are not taking more advantage of online channels. Moreover, especially the smaller galleries are torn between keeping their traditional business alive while adapting to new trends (Smith et al. 2006).

Despite these limitations, it is worth looking at the current developments in the online art market. In recent years, various new businesses focusing on online art sales have emerged. There are now several online marketplaces, art galleries, and auction houses that try to facilitate the purchase of artworks (Sidorova 2019). Artsy, for example, is a website that matches potential buyers with galleries, enabling galleries to present themselves to a broad audience and providing customers suggestions tailored to their personal taste (Arora and Vermeylen 2013). The platform Saatchi Art is a direct intermediary, meaning thatmostly young and less established-artists can directly offer their works for sale without the need to be represented by a gallery. Prices are transparent and search filters allow customers to look for their desired artwork (Kohle 2014; Polleit-Riechert 2010). Several high-end galleries, including the David Zwirner Gallery, have recently started offering viewing rooms on their websites, where visitors can find a high-quality presentation of exhibitions, often with the addition of prices. Other galleries have started offering artworks for sale in their own online shops. This is facilitated by the possibility, today, of easily creating high-resolution images, virtual reality visualisations, and an interactive experience online (Lee and Lee 2019). Overall, the potential of new business opportunities through the implementation of the Internet should not be underestimated, especially if one considers that younger generations are familiar with using online channels for purchasing products and services of any kind (Blumenthal 2013; Lee and Lee 2019).

\subsection{The Multi-Channel and Omni-Channel Approach}

A business model is highly dependent on environmental factors such as technology, competition, and market developments. Therefore, it needs to be constantly reviewed andif necessary-adapted in order for the business to stay competitive (Cortimiglia et al. 2013). The integration of digital channels into the business model of galleries can take various shapes. A report by Ernst \& Young (2012) proposes three options for how companies can leverage digital channels for their business. The first option is to use digital technology to enhance the traditional business model. Here, for example, digital and automated services could be offered as an extension to existing services. The second option is to transform the existing business model into a digital one. This involves offering entirely new services that do not exist in the analogue form or offering existing services in digital form. The third option is to generate a completely new business model, offering new products and services, and generating new revenue streams (Ernst \& Young 2012). As previous research suggests, the business and social context of art galleries, as well as the specific characteristics of the art market, make it difficult to sell art online while maintaining the traditional gallery business model. The use of digital channels as an additional component amplifying the business model (Ernst \& Young 2012) therefore seems to be the most suitable for galleries. 
Research on the multi-channel theory focuses on the integration of multiple channels into one overarching system (Ganesh 2004; Neslin et al. 2006). In general, offering digital channels while keeping them siloed often results in inconsistencies between the physical and digital channels; for example, if information is not synchronised (Ernst \& Young 2012). In order to increase customer value, the various sales and communication channels should be coordinated and offer a consistent customer experience (Stone et al. 2002). Customers should be able to interact, search for information, purchase products, and handle returns on all channels, as well as switch between those channels interchangeably (Kumar and Venkatesan 2005). If information is successfully and consistently integrated into all channels, customers experience convenience (Kumar and Venkatesan 2005). This seamlessness of use between channels plays a crucial role in customer loyalty, for example, when a product can be purchased online but picked up at a store (Bendoly et al. 2005; Neslin et al. 2006).

A more advanced version of the multi-channel integration is the omni-channel concept. According to omni-channel theory, customers move freely between physical stores and online shops during a transaction process. In order to make the transition even more seamless and easy, this concept implies further possibilities of channel integration such as mobile phones, social media, and sometimes even gaming (Piotrowicz and Cuthbertson 2014). Piotrowicz and Cuthbertson (2014) suggest that, although channels are integrated into an overarching system, the experience, feeling, and seeing of certain products, as well as the shop atmosphere itself, are still important components for customers. With the convenience of shopping online, they suggest that stores in the future might have the character of showrooms which still offer the experience of entering a shop, getting advice, and looking at the products. However, this scenario will presumably still take some time since older generations often need the face-to-face interaction with sales personnel and buy the product in the shop (Piotrowicz and Cuthbertson 2014).

\section{Methodology}

\subsection{Choice of Method}

This research is both exploratory and explanatory in nature. This is especially useful when previous research on the topic is limited (Kumar 2019; Matthews and Ross 2010). The main objective is to explore which topics the participants find relevant and important with respect to the research question. Moreover, we aim to understand why participants perceive social phenomena in a specific way and to gain insights into their experiences, opinions, and feelings regarding a certain topic (Kumar 2019; Matthews and Ross 2010). To do so, we utilise qualitative research methods, thereby providing a richer understanding of the context, rather than the generalisable insights that may result out of a statistical approach. We conducted 20 semi-structured, in-depth interviews and for this we constructed a topic guide based on the theoretical framework. The in-depth interviews focus on capturing the social world by documenting and interpreting the perspective of its participants (Bryman 2012). For the analysis of the data, the method of thematic analysis was applied. This method helps to identify and analyse patterns of meaning in a data set. The process ranges from purely describing and summarising the data, to interpreting the data, and, finally, defining its broader meaning and detecting recurring patterns (Braun and Clarke 2006). According to Clarke and Braun (2013), a thematic analysis is particularly useful for analysing people's understandings and experiences related to the research topic.

\subsection{Selection of Participants}

Purposive sampling was selected as the sampling method. According to Matthews and Ross (2010), it is often used for research where the focus is on in-depth insights and qualitative results, with participants being selected based on predefined characteristics. Various population criteria in terms of location, and respondents' function and affiliation were defined before conducting the interviews. The selected galleries are based in or around Vienna and Salzburg or, if they operate on an international level, they at least have one of their branches in one of these cities. Vienna was selected for several reasons: it is 
both a nationally and internationally renowned centre for art and culture; it has a wellestablished art scene with several renowned museums, art galleries, and other art-related institutions (BMWFW 2017); it is the capital and biggest city of Austria. Salzburg is a popular tourist destination and, with its internationally acclaimed Salzburg Festival, it is an important cultural hotspot. The gallery scenes in Vienna and Salzburg include both galleries with a national and international focus, which in turn implies that the results of this research are more representative of a broader variety of gallery types than a study solely based on smaller galleries with a local or national focus. The selected interview partners are either owners, directors, or managers of a gallery, or have another managerial position within a gallery. They have a good understanding of and expertise in the current national and international art market developments. We contacted both contemporary art galleries and art dealers, as we assume that both are affected by the increasing importance of digital channels related to their business. It was decided to investigate the perspective of gallery owners and managers rather than the perceptions of buyers. This is supported by the fact that they usually have many years of professional experience and thus have extensive practical knowledge of the complex processes of the art market as well as their specific business field.

\subsection{Data Collection and Analysis}

Since there are no general registers of all art galleries in Vienna and Salzburg, we compiled a list of galleries based on several sources. ${ }^{8}$ This resulted in a list of 95 galleries, consisting of both art dealers and contemporary art galleries. Of these, a total of 55 galleries were contacted in March and in October 2020 and were informed about the research topic. It was carefully considered that a good mix of contemporary art galleries and art dealers, as well as of Alpha, Beta, Gamma, and Delta galleries (see Section 2.2), were included. Therefore, the sampling strategy can be described as purposeful, as the selection was not random but rather focused on ensuring a good variety in the sample (Bryman 2012). Apart from this, five participants were selected by convenience sampling, i.e., they were selected based on the availability to the researcher (Bryman 2012). In concrete terms, this means these five participants were recruited through personal contact. ${ }^{9}$

A total of 22 galleries volunteered for the interviews, of which 20 then took place. The final data set consists of a total of 20 in-depth interviews, of which fifteen participants are the founders and directors of a gallery and five have a managerial role in a gallery. The Appendix A presents a short overview (Table A1) of all participating galleries, their gallery type as defined by Resch (2011), and additional information regarding their focus and size.

Before conducting the interviews, the participants gave their written consent for the interview to be audiotaped and used for the purpose of this research. The duration of the interviews varied between 47 and $95 \mathrm{~min}$, with a total duration of $1256 \mathrm{~min}$ and an average duration of around $60 \mathrm{~min}$. Due to the restrictions of personal contact in the context of COVID-19, the interviews had to be conducted via phone or video calls. The first round of interviews was conducted in April 2020, and the second round took place between October and November 2020. We transcribed all interviews manually and subsequently coded them using the qualitative data analytic software ATLAS.ti. ${ }^{10}$ Three rounds of coding were performed, based on Corbin and Strauss (1990), namely open coding, axial coding, and selective coding. First, the initial open coding was carried out. Here, we assigned smaller sections that form a thematic unit and are relevant to the research question to a code describing the content or topic. The initial codes resulted in a long list of terms and concepts, which allowed the formulation of the topics covered in the interviews. In the second stage, axial coding, we processed coherent codes and created and tested categories with corresponding sub-categories. In the third phase, selective coding, we defined a central core category around which the other codes, themes, and categories were arranged. This resulted in the central focus of the research topic and, in this case, is labelled as "the impact of digital channels on the business of art galleries". To provide insight into our analysis, we added the most relevant codes for each gallery in Table A1 (Appendix A). 


\section{Results and Discussion}

\subsection{Attitudes towards Online Channels}

In this first section, we analyse how and to what extent our respondents generally have been using digital channels (before the pandemic). We found that galleries in every category nowadays use online channels at least for basic purposes such as publishing news and exhibition information on the gallery website, sending newsletters, or posting on social media. Most interviewees consider the gallery website to be the most important of all online channels. This is followed by social media channels-especially Facebook and Instagram - and some galleries are also members of intermediary sales platforms such as Artsy. We found that especially the locally oriented Gamma and Delta galleries are noticeably less active online than the internationally oriented galleries. They usually offer only basic information about the gallery, artists, and exhibitions on their website and claim that their business is focused on the actual gallery space. Likewise, they do not deem social media to be relevant as they are not reaching their client base. These galleries are usually not present on sales platforms, since this often involves high costs and requires a decent reputation to gain visibility. The Alpha, Beta, and some internationally active Gamma and Delta galleries report utilising their websites more comprehensively, for example by providing detailed information about the gallery program and the artists, or by offering their artworks for sale. Their goal is to provide potential buyers with highquality and insightful information. For these galleries, social media is highly relevant for marketing and communication, and they regularly share gallery offerings and insights (e.g., exhibitions, events, and art fairs). Some of the internationally active galleries are also present on intermediary sales platforms and regard them as relevant channels to reach their international client base.

The findings support what Arora and Vermeylen (2013) stated: digital channels such as websites and social media are now used by almost every gallery for marketing and communication. Our results, however, provide a more granular picture: galleries with a local or national clientele-mostly Gamma and Delta galleries-tend to have a reduced online appearance, with basic information. Alpha and Beta galleries, and some Gamma and Delta galleries that are active on the international market, have a more elaborate, complex, and extensive use of online channels.

\subsection{Sales Integration}

Apart from more general perspectives on the employment of digital channels, we explored different stances towards online art sales. While previous scholars have generally rejected online sales (e.g., Arora and Vermeylen 2013; Samdanis 2016; Sidorova 2019), we found that more than half of the respondents had a positive opinion on selling art online. Six galleries have their own online shop and five have a profile on mediating art sales platforms (e.g., Artsy); in both cases, the artwork can be purchased directly online. Additionally, two galleries display the artworks currently offered for sale with prices on their website. In line with the more general use of online channels, the majority of these galleries have an international market orientation.

We found that five out of the six galleries with an online shop are located in the lower (to mid-) price segment or offer artworks up to a certain price level (max. 4000 Euros). This coincides with previous research, where it was often reported that online sales are most likely to happen in the lower price segment (Adam 2014; Fassio 2019; Khaire 2015; Samdanis 2016). Surprisingly, several interview partners of more exclusive galleries reported that they sell art even on a mid- and higher price level through digital channels; however, in a more concealed form. For instance, four renowned galleries in the higher price segment report that they receive inquiries via online channels (e.g., following an Instagram post or a newsletter), often leading to sales. The director of a Beta gallery recalls that a customer recently bought a six-figure artwork online without ever physically seeing it. Another gallery director reaffirms that online sales at higher price levels are becoming more popular: 
Yes, this really happens more often now. [...] I have also already found some artworks myself [on social media]. I bought an artwork that I found by chance while scrolling through [the feed] and I thought 'Oh God, unbelievable, I need to have this one'. (Gallery director, gallery 6)

From the interviewees' statements, we conclude that art can also be sold online at higher prices, because internationally renowned galleries generally enjoy a good reputation and represent well-known artists, thus offering buyers sufficient security when buying art online. Regardless of the price level, we found that online art sales are more popular for galleries operating on the international market, while the regional or national galleries are less successful in that area. Interestingly, the analysis shows that certain regions and countries, including North America, South America, and Asia, are particularly active in the online sector.

Our analysis allows an evaluation of why online shops are not providing the ideal setting for selling art in the mid- and high price segment. One of the main constraints we identified is the plain presentation of artworks with basic information in online shops, making it hard to evoke emotions among viewers. In contrast, galleries dedicating time and work to create engaging content on online channels provide a more emotional experience, allowing visitors to connect with the artist and the artwork in a personal way. This shows that both captivating and curated content is important in the online space, especially for high quality art. A gallery director points out that many international art galleries, such as David Zwirner Gallery (Alpha gallery), have launched online viewing rooms on their websites in recent years. There, current exhibitions are made available with curated texts, video, and photo content, and possibly also prices. Moreover, several respondents remark that an online shop format may appear as too commercial for high-end art. The statement of a Beta/Gamma gallery in the mid-price segment demonstrates this perspective:

A real online shop, where there's a purchase function, [...] where you click on the picture and then add it to your shopping bag and you select the shipping method, I wouldn't want that, because it's too commercial for me, too similar to shopping at Amazon or for consumer goods. (Gallery founder and director, gallery 13)

Since art at a lower price level generally has a rather decorative character (Knebel 2007; Throsby 1994) and the acquisition does not involve significant financial risk, Gamma and Delta galleries are successfully selling art through online shops. In the middle and high price segment, confidence, emotional engagement, and trust in the gallery and artist are important factors that need to be conveyed online. This can be achieved best with a professional online appearance, well-curated and captivating content, and sufficient information about the artistic concept. Hence, online art sales are now also commonplace for Alpha and Beta galleries selling expensive art. These galleries make use of immersive experiences beyond simply online shops. The findings can be linked to research on luxury goods (e.g., Hennigs et al. 2012), where it was found that high-quality goods sold online need to be presented in a visually appealing way and should engage the viewer with videos, visualisations, and photos.

\subsection{The Impact of COVID 19}

With regard to the general change in sentiment towards digital channels, we noticed that many participating galleries had already expanded their online presence to a certain extent in the past years. Notably, this process was accelerated with the outbreak of the global pandemic. All of a sudden, galleries worldwide were forced to engage with their audience and client base through digital instead of traditional channels. We observed that galleries of all four types started experimenting with new tools and started new initiatives. A gallery founder mentioned that he started recording podcasts with artists, curators, and market experts; others created video recordings of exhibitions, 3D exhibition views, or guided video tours, and some reported that they worked on a more professional and extensive online presentation of the artists, exhibitions, and artworks. A gallery director, for example, explains that she had re-worked the entire online appearance of her gallery 
during the first weeks of the lockdown and even started filming guided tours through the exhibition. She notes:

The current times require us to be more open towards technology and the digital world. And most people are very enthusiastic about it. I currently have collectors in Gastonia, America, who are totally excited about the video because it allows them to see the exhibition. (Gallery director, gallery 7)

Another gallery director reports that his gallery has undergone a complete makeover. Previously, the gallery only provided basic information on its website, but noticed a change of habits and new market requirements. In the past months, the director decided to relaunch the website and to share insightful information about artists and their exhibitions. Interestingly, he now even considers the website to be a vitally important extension of the gallery space.

Consistent with the observation that Alpha and Beta galleries, and some internationally active Gamma and Delta galleries, already had a stronger online presence before the pandemic, we found that these galleries continued to grow their online reach and improved their appearance on the Internet during the COVID-19 outbreak. In contrast, Gamma and Delta galleries with a national or local focus only made necessary adaptions to maintain visibility while their spaces were closed. They frequently mentioned that, for them, online channels might be important incentives to attract potential customers to the gallery, but that online sales would not work for them. These galleries emphasise that the buying decision is mostly made in the gallery and that buyers need to be persuaded on a very personal level. The founder of a small gallery representing young Austrian artists, for example, explains:

Well, [ ... ] people get a first impression [online] but then come to the gallery, even if they have already seen the work online and liked it. But then they come to the gallery to see it live here and then the buying decision is made. (Gallery founder, gallery 15)

Consequently, these galleries did not significantly invest in new tools or increase their online activity, but rather approached their existing network of potential buyers in a personal manner (e.g., calls and e-mails) and waited until the restrictions were lifted.

\subsection{Online Art Sales and Specific Pre-Conditions}

To gain a better understanding of why galleries are reluctant to fully integrate online (sales) channels into their business models, we build on the findings of previous research and aim to further explore the circumstances and specific business context. The first aspect mentioned by the majority of interviewees is the customer need to experience art in reality to make a purchase decision. Many argue that seeing a digital reproduction cannot replace this experience. A gallery manager demonstrates the importance:

You sell material goods that are unique. So, we're talking about material goods that are not standard, that owe their high prices precisely, and to a large extent to aesthetics. Thus, it is particularly this added value [of art] that needs to be experienced visually, because in the end you always enjoy a concrete, physically tangible artwork and not a digital image. (Gallery founder, gallery 2)

Due to the unique character of each art piece, its quality can best be assessed through physical observation. Moreover, many experts-especially owners of Alpha and Beta galleries-mention the necessity to build trust and emotionally engage the viewer. The director of gallery 13 explains: "I don't think that someone who has never seen the artist or [who] has no information, finds the artwork online—especially at a higher price level—and then simply says: 'Yes, I'll buy that one, I'll purchase the painting'." These statements are in line with previous research, where it has been emphasised that art is an experiential good and, therefore, requires a physical context and experience (Arora and Vermeylen 2013; Bayer 2018). 
A second aspect restricting online art sales is the importance of personal interaction and networking. Almost all experts, covering all four gallery types, consider the maintenance of personal relationships and active engagement with their network as essential activities. The statement of a gallery director demonstrates that the art network is needed to create and maintain the artist's and gallery's reputation and credibility, and to deliver value to customers:

Around 90 percent [of my clients] come from personal contacts or contact of artists or collectors or friends of collectors [...]. Hence, they are all intentionally visiting the gallery. And there are very, very few people who walk by, look through the shop window and think: 'Ah, I'm going to have a look at the gallery now'. (Gallery founder, gallery 13)

As stated in previous research, it's among the galleries' duties to ensure that their artists are respected in the art world and, in doing so, they build and maintain the symbolic and economic value of the artworks they selected (Janssen and Verboord 2015; PolleitRiechert 2010; Velthuis 2011a, 2011b). We found that these trustful relationships are particularly important for more exclusive Alpha and Beta galleries, as the acquisition process of high-end products is more complex. Gamma and Delta galleries selling in the lower price segment, on the contrary, have more spontaneous buyers and walk-in customers. With the business model strongly depending on personal communication of information and close relationships, online art sales are challenging with regards to emotional and personal engagement and conveyance of trust.

A third aspect we identified as a constraint for selling art online is the demand for events and social interaction. Several interviewees state that gallery events such as exhibition openings, talks, or private dinners are common ways to build and maintain long-term customer relationships. We ascertained that the customer journey needs to go beyond the sales process, and that such events offer a sense of social belonging as well as an emotional and personal involvement in the art scene. Online art sales, in contrast, are anonymous, impersonal, and are therefore not offering the established conditions for selling art.

The fourth aspect we discovered as a challenge for online sales is the exclusive and non-transparent character of the art world. This is demonstrated, for example, by the lack of price transparency. The majority of galleries indicate not making prices publicly available. However, we observed that Gamma and Delta galleries in the lower price segment tend to be more transparent with prices (e.g., online stores, price lists, price tags). On the contrary, Alpha and Beta galleries in the mid- to high segment are more exclusive and argue that they want to be in personal contact with the potential customer. The statement of a Beta/Gamma gallery gives a frequently used explanation as to why prices are only made available upon request:

For the simple reason that we want to get into a conversation with the customer.

And if someone now asks about the price, then you already have the basis for

a conversation, and then you can tell them more about an artwork and so on.

(Gallery manager, gallery 14)

When asked for other reasons why galleries appear exclusive and are handling information so secretly, an interesting pattern was found. Most interview partners were not able to provide a clear explanation and some assumed that this partly is due to established rules and traditions that galleries are striving to follow. The director of gallery 6 , for example, states: "I don't know exactly, but I think it's like saying: 'It has always been like that'. And it's somehow considered good and elegant not to show the prices so prominently." This coincides with what Dowling and Pfeffer (1975) describe as organisational legitimacy, meaning that companies are striving to align their internal social values with the values of their larger social context. Consequently, galleries are following established rules to gain legitimacy and respect in their field. Other respondents mention that exclusivity also helps 
galleries to create value around artists and their work. An art dealer (gallery 9) explains why:

The value is not measured by the object itself; the value is measured by who comes in, the value is measured by the customer. [ ... ] And because calculations [for art] are so artificial and arbitrary, of course many people who are involved in this system want to keep it as opaque as possible.

We found this particularly evident for Alpha and Beta galleries in the mid- and higher price segment. On one hand, exclusivity helps to establish and retain a certain clientele, which in turn is beneficial for the galleries' and artists' reputations. On the other hand, it also gives galleries control over their client base and enables them to maintain and increase their reputation and value in the art scene. Gamma and Delta galleries in the lower price segment, however, tend to be advocates for greater market transparency and critically reflect on the necessity of exclusivity.

Also, we found that exclusivity is associated with the desire of galleries to not appear as commercial and profit-oriented. This statement of a gallery founder illustrates that galleries are uncomfortable putting the commercial and monetary aspect more centrally in their perception of art:

It's not always just about earning money with it and saying: 'Yes, here's the artwork and this is how much it costs.' But it is also about discussions and about issues that are raised by these artworks. And perhaps some are afraid that such discussions are devalued by something pragmatic like the price $[\ldots]$. So, you somehow want to exclude the commercial, because you have the feeling that it distracts from the actual topics in art. (Gallery founder, gallery 16)

Several interviewees also mention that the art market has become more commercial in the past years. This means art is increasingly turning into a commodity and is thus valued differently than in the past. Consequently, it can be assumed that galleries are also afraid of losing legitimacy and putting the economic aspect too much in the foreground when selling art through online channels and providing information in full transparency.

Apart from that, a fifth aspect limiting galleries from extensively using digital channels is the limited resources of galleries. Galleries tend to be small businesses with few employees. Accordingly, we found that the capacities for regularly producing online content and constantly maintaining online channels are scarce. The manager of gallery 14 , for example, reports from her learning that online channels cannot be managed on the side, but that it requires a full-time team member who produces online content and regularly updates all platforms. Moreover, several experts claim that high costs for professional content production pose a hurdle for them. As a general observation, galleries with a local or national focus and smaller teams are struggling with these conditions, while those with an international focus and larger teams have more resources. These findings are in line with previous research, suggesting that cultural entrepreneurs often lack organisational skills and financial literacy (de Graaf et al. 2019). It shows that especially the smaller Gamma and Delta galleries are struggling due to their limited business capacities.

The five aspects we presented above allow the following conclusion for online sales. A more extensive use of online channels asks for a greater transparency of information which may lead to a broader audience. However, this poses certain risks to established business mechanisms, especially for more exclusive Alpha and Beta galleries. The results re-confirm some aspects that have been addressed in previous research, but that were not necessarily placed in the context of online channels and its potentials and risks. It can be concluded that, for Alpha and Beta galleries active on the international market, factors such as organisational legitimacy, exclusivity, discretion, a good reputation, and maintenance of economic and symbolic value are posing challenges for becoming more open and transparent. Local or national Gamma and Delta galleries are rather confronted with aspects such as limited financial and personnel resources. 


\subsection{The Multi- and Omni-Channel Approach}

Most interviewees believe that online art sales without any personal interaction are unlikely to succeed. Hence, online sales channels should be regarded as extensions to other more traditional channels. Digital channels offer additional possibilities for customers to approach galleries, acquire information, and purchase artworks. From our analysis, it is clear that most online purchases are made by people who are already familiar with the gallery or artist, and who had often even acquired an artwork from the gallery or artist before. This is reported both by galleries with an online store as well as galleries that sell through other online tools (e.g., newsletters, social media). Innovating the gallery business model can therefore best be achieved by what is described as the integration of digital technology as extensions to existing services in the report by Ernst \& Young (2012). Consequently, the multi- or omni-channel approach is a suitable solution for galleries to implement digital channels.

Our analysis revealed that some galleries have already implemented this concept to a certain extent, for example, by presenting and offering artworks on the website, and using newsletters and social media as complementary communication channels to their traditional ones. Seven interview partners stated that the combination of physical presentation in the gallery and at fairs, combined with an online presentation, is beneficial to their success. The following statement of a gallery director (gallery 1) illustrates the importance of synchronising both online and offline channels:

Well, I think a good website is really important. Because people either go to the website first and see things and then they come [to the gallery] and they want to see it. Or if they see it here, then maybe they read about the artist again on the Internet, read about the artwork and so on. So, the combination is really good and is very important. (Gallery founder, gallery 1 )

With the multi- or omni-channel strategy, galleries are able to offer a high service quality on all channels, and customers are able to choose according to their preference. While personal conversations and the gallery space are still essential elements, with this approach galleries are able to implement digital channels in a meaningful way. For example, a prospective buyer can obtain more general information and complete the purchase process online, while more personal channels such as e-mails, phone calls, and visiting the gallery serve to provide more in-depth information. This is in line with Kumar and Venkatesan's (2005) view that each channel has its own advantages and disadvantages, but in sum they complement each other. Following Piotrowicz and Cuthbertson (2014), the gallery space and booths at art fairs would then function mainly as showrooms, where the social interaction, experience, atmosphere, and personal support are provided, while the digital channels primarily serve as informative and sales channels.

Galleries considering implementing online channels into their business model should make sure to keep the barriers to personal communication low and to respond to the individual needs of every customer. The director of gallery 7 , for example, explains that she adapts to the communication needs of her customers as much as possible and is available to them on many channels in order to offer a convenient customer experience. Based on the findings presented above, we conclude that a multi-channel or omni-channel approach is suitable for all four gallery types; however, it requires an openness to greater information transparency and enough resources for continuous maintenance.

\subsection{Business Transformation in the Context of the COVID-19 Pandemic}

As has become clear, the outbreak of the COVID-19 pandemic has accelerated the previously slow process of digitisation in the gallery business model. What remains to be discovered is the extent to which these new developments will actually persist. During the first round of interviews, several experts commented on the over-saturation of online offers in the course of the first lockdown in spring 2020 and believed that this would be only temporary. In the later course of the study, we observed that even the more critical galleries started providing information online. Another interesting observation is that 
during the early phase of the pandemic, galleries were experimenting with various formats and offerings. Those interviewed at a later point already had a more elaborate strategy through their experience gained in the previous months. They were more sophisticated in why they are (not) making use of digital channels. It can be assumed, however, that galleries which made major improvements in their online appearance and successfully sold art online will continue with their strategy after the pandemic.

Overall, the findings show that, because of COVID-19, galleries are being forced to become more transparent through digital channels, thereby lowering the barriers for everyone involved in the market. This could pose certain risks for the galleries. For example, the function of galleries could lose relevance and alternative forms of selling art, such as digital platforms, could become more popular. Some interviewees state that many artists are nowadays representing and managing themselves and that it has become easier to self-market oneself on the Internet. Others believe that it is exactly this overflow of information that makes art galleries indispensable, as they serve as quality filters and help with artists' market positioning. The director of gallery 2 explains this as follows: "I always compare the gallery owner with the hunter in the forest. And this is a necessary metaphor for the functioning of the art market system [...]. That won't change". Even if the gallery business will continue to follow its own laws, the pandemic has led to the acceleration of digitisation processes and has brought a variety of new opportunities for presenting and selling art. The findings of this study suggest that a hybrid and synchronised form of digital and traditional channels will most likely succeed in transferring the strengths of the traditional model to a new reality.

\section{Conclusions}

In this study, we provide insight into how managers and directors of galleries deal with the growing digital possibilities in their strategic environment, with particular emphasis on the global COVID-19 pandemic. We take into account that there are four different types of galleries with respect to their organisation size and degree of internationalisation. Our findings lead us to the conclusion that digital technology has implications for the traditional business model of every gallery type.

The results indicate an increasing openness to innovation through digital channels. We found that all galleries are nowadays using basic online digital tools, such as their own website, social media, and newsletters for promotion and visibility. An interesting observation is that Gamma and Delta galleries with a local or national client base have a reduced online presentation, while the Alpha and Beta galleries and some internationally active Gamma and Delta galleries show a more comprehensive and elaborate use of online channels. When it comes to online sales, we found that more than half of the respondents had a positive opinion about selling art online, suggesting an increasing openness. These galleries tend to be those with an international clientele rather than a local focus. While previous research suggests that online sales are a good match for the lower price segment (Adam 2014; Fassio 2019; Khaire 2015; Samdanis 2016), we observed that this has changed. For the Gamma and Delta galleries active in the lower price segment, art tends to be sold through common online shops, while for Alpha and Beta galleries in the mid- to high price segment, art is sold in more complex and concealed ways (e.g., via online enquiries through social media or online viewing rooms). These findings indicate that even more exclusive art can successfully be sold online, if the gallery and artist enjoy an international reputation, if the acquisition context is not overtly commercial and if the provided content is well-curated and presented in a captivating way.

The outbreak of the COVID-19 pandemic accelerated the previously slow process of digitisation in art galleries. We saw that galleries of all four types began to experiment with new digital opportunities, hoping to reach clients and interested people in other ways than the more traditional ones such as the gallery space or art fairs. While some started transferring parts of their activities online with online talks, live streams, videos, filmed guided tours, 3D-exhibition views, and other online content formats, others used the time 
to polish and professionalise their online presentation. Again, Alpha and Beta galleries, as well as some internationally active Gamma and Delta galleries, were more open to investing in digital visibility. The local Gamma and Delta galleries only made basic changes and launched easy-to-implement features, or generally waited until restrictions were lifted again. They explain that, for them, personal interaction is essential, as they need to put much effort into convincing each potential buyer.

Within our research, we identify and highlight the aspects that are limiting galleries in fully embracing digital channels for their businesses. In short, these are: plain presentation of information online; lacking or distanced personal interaction; online anonymity that disconnects from the social art environment; increased information and price transparency; a more commercial appearance; limited resources for digital adaptations. The findings in our study emphasise the importance that is placed on experiencing art physically in order to evaluate the quality, evoke emotions, and build trust. Galleries tend to foster very personal and close relationships with their customers, and it is difficult to create online transactions with the same degree and effects of personal interactions.

Our results suggest that participants view online sales much more positively than would be expected, based on previous research (e.g., Arora and Vermeylen 2013; Kohle 2014; Samdanis 2016; Sidorova 2019). Many galleries are starting to explore a hybrid online and offline business model. Following previous findings on multi- and omni-channel business models (e.g., Kumar and Venkatesan 2005; Piotrowicz and Cuthbertson 2014; Stone et al. 2002), galleries are advised to focus on a more comprehensive and personal presentation in the online area, combined with easily accessible possibilities of personal interaction (e.g., request buttons). In order to generate trust and confidence among potential customers to buy art online, galleries need to provide rich information on artworks, artists, gallery activities, and the gallery itself. They should ensure that each touchpoint with the gallery offers a meaningful experience that is integrated into an overarching strategy. For example, we suggest enhancing the online experience by: virtual exhibition views for potential clients; an introduction of the gallery staff and gallery history to connect with visitors on a more personal level; informative video and photo material about artists and their work practice; podcasts and Instagram talks with artists and experts; other interactive features that balance out the lack of emotional engagement. An omni-channel strategy for galleries allows digital as, well as remote, channels to complement each other. It is a solution for galleries to connect the traditional remote channels and need for physical experiences with the customers' growing demand for the digital availability of information and products.

While the multi- and omni-channel strategy currently makes the most sense for galleries with international clientele, it may become more relevant for locally oriented galleries in the future, considering that "digital natives" are increasingly falling into the group of potential art buyers and that the pandemic has sped up the digitisation process. In the past months, there has been a stark increase in digitally available information in the art sector. Especially during lockdowns, many cultural offers migrated to online channels. While the long-term effects of these developments cannot be currently predicted, it can be assumed that people will be left with a significant change in habits/attitudes. Over a longer period of time, all four gallery types will benefit from integrating online channels into their business model. While, for smaller Gamma and Delta galleries, limited capacities to invest time and money in an elaborate online presence can be a challenge, the more exclusive Alpha and Beta galleries need to find a balance between providing easily accessible information and maintaining control over organisational legitimacy and reputation if they consider online channels to be essential to their success. Ultimately, it can be assumed that galleries that made major improvements during the past months and successfully sold art online will pursue their strategy, while others will follow these trends with a delay or will retain their traditional business model.

Although this research has been conducted following widely used methods, there are certain limitations. It should be noted that qualitative research does not allow generalising results to a broader context. A statistical approach that further investigates our findings 
would allow more generalisability and may, for example, show how the COVID-19 pandemic facilitated and accelerated particular online marketing strategies. Vienna has both nationally and internationally active galleries in various price ranges. However, the city is not among the most important art centres worldwide (McAndrew 2019). Nevertheless, this study provides an insight into the current sentiment and offers a perspective for gallery owners and managers on how to best integrate digital channels into their business model. Further exploration of the topic could also focus on gaining a more comprehensive understanding from different perspectives and countries. Other markets, such as the Asian and American market, which many experts have described as more open cultures towards online sales, could be a topic of further investigation. In addition, the perspective of younger generations, as well as artists, art collectors, and other art market experts could provide an even more comprehensive picture of the effects of the pandemic and on how, for example, galleries are able to connect to new clients. An interesting aspect that was not discussed in detail is how the two tendencies-the increasing importance of digital channels on one hand and the increasing popularity of personalised experience on the other hand-could be combined. Further research could therefore look at new possibilities for art galleries, with a particular focus on expanding the traditional business model. Likewise, further research could focus on an intensive exploration of the advantages and disadvantages of a multi-/omni-channel approach for art galleries.

Author Contributions: Formal analysis, B.E.M.H.; data curation, B.E.M.H.; writing-original draft preparation, B.E.M.H. and P.V.B.; writing-review and editing, P.V.B.; supervision, P.V.B. All authors have read and agreed to the published version of the manuscript.

Funding: This research received no external funding.

Informed Consent Statement: Informed consent was obtained from all subjects involved in the study.

Conflicts of Interest: The authors declare no conflict of interest.

\section{Appendix A}

Table A1. List of Galleries, their Categorisation and Relevant Codes.

\begin{tabular}{|c|c|c|}
\hline Gallery & Gallery Type & Codes/Tags \\
\hline $\begin{array}{l}\text { Gallery } 1 \\
\text { Contemporary art gallery }\end{array}$ & $\begin{array}{l}\text { Beta/Gamma gallery } \\
\text { Mid-sized gallery } \\
\text { International and national client base } \\
\text { Mid-price segment }\end{array}$ & $\begin{array}{l}\text { Extensive information on website } \\
\text { Web-shop } \\
\text { Online art sales } \\
\text { Frequent use of social media } \\
\text { Minor changes during pandemic } \\
\text { Mix of spontaneous and long-term clients } \\
\text { Prices and information are transparent }\end{array}$ \\
\hline $\begin{array}{l}\text { Gallery } 2 \\
\text { Contemporary art gallery }\end{array}$ & $\begin{array}{l}\text { Beta/Gamma gallery } \\
\text { Small-sized gallery } \\
\text { Mostly national client base } \\
\text { Mid-price segment to higher price } \\
\text { segment }\end{array}$ & $\begin{array}{l}\text { Basic information on website } \\
\text { Basic use of social media } \\
\text { Minor changes during pandemic } \\
\text { (improvements on website) } \\
\text { Personally contacted existing network } \\
\text { during pandemic Waited until } \\
\text { restrictions were lifted } \\
\text { Emphasises the importance of } \\
\text { experiencing art } \\
\text { Long-term relationships with clients } \\
\text { Prices and information are intransparent }\end{array}$ \\
\hline
\end{tabular}


Table A1. Cont.

\begin{tabular}{|c|c|c|}
\hline Gallery & Gallery Type & Codes/Tags \\
\hline $\begin{array}{l}\text { Gallery } 3 \\
\text { Contemporary art gallery and art dealer }\end{array}$ & $\begin{array}{l}\text { Beta/Gamma gallery } \\
\text { Mid-sized gallery } \\
\text { Mostly national client base } \\
\text { Mid-price segment to higher price } \\
\text { segment }\end{array}$ & $\begin{array}{l}\text { Average use of website } \\
\text { Basic use of social media } \\
\text { No changes during pandemic } \\
\text { Personally contacted existing network } \\
\text { during pandemic } \\
\text { Emphasise the importance of } \\
\text { experiencing art } \\
\text { Long-term relationships with clients } \\
\text { Prices and information are intransparent }\end{array}$ \\
\hline $\begin{array}{l}\text { Gallery } 4 \\
\text { Contemporary art gallery }\end{array}$ & $\begin{array}{l}\text { Gamma gallery } \\
\text { Small-sized gallery } \\
\text { National and international client base } \\
\text { Lower price segment to mid-price } \\
\text { segment }\end{array}$ & $\begin{array}{l}\text { Basic information on website } \\
\text { Basic use of social media } \\
\text { No changes during pandemic } \\
\text { Waited until restrictions were lifted } \\
\text { Emphasise the importance of } \\
\text { experiencing art } \\
\text { Spontaneous buyers } \\
\text { Prices and information are transparent }\end{array}$ \\
\hline $\begin{array}{l}\text { Gallery } 5 \\
\text { Contemporary art gallery }\end{array}$ & $\begin{array}{l}\text { Alpha/Beta gallery } \\
\text { Mid-sized gallery } \\
\text { National and international client base } \\
\text { Lower price segment and higher price } \\
\text { segment }\end{array}$ & $\begin{array}{l}\text { Extensive information on website } \\
\text { Web-shop (for cheaper artworks) } \\
\text { Membership on art sales platform (Artsy, } \\
\text { Widewalls) } \\
\text { Very active on social media } \\
\text { Online art sales } \\
\text { Sales inquiries through social media } \\
\text { Changes during pandemic (more } \\
\text { engagement on social media) } \\
\text { Mostly long-term relationships with } \\
\text { clients, some spontaneous buyers } \\
\text { Prices are transparent for lower, but not } \\
\text { for higher price segment } \\
\text { Information is transparent }\end{array}$ \\
\hline
\end{tabular}

Extensive information on website

Very active on social media

Alpha/Beta gallery

Mid-sized gallery

International client base

Mid-price segment to higher price segment
Online art sales

Sales inquiries through social media Changes during pandemic (exhibition videos, participation in new online formats)

Long-term relationships with clients

Prices are intransparent

Information is transparent

Extensive information on website

Very active on social media

Membership on art platform

Beta gallery

Mid-sized gallery

International client base

Gallery 7
Contemporary art gallery
Mid-price segment to higher price segment
(Artorigo-smaller platform)

Prices indicated on website (up to $4000 €$ )

Online art sales

Sales inquiries through social media Major improvements during pandemic (new website, video gallery tours, etc.) Long-term relationships with clients Prices and information are transparent 
Table A1. Cont.

\begin{tabular}{|c|c|c|}
\hline Gallery & Gallery Type & Codes/Tags \\
\hline $\begin{array}{l}\text { Gallery } 8 \\
\text { Contemporary art gallery }\end{array}$ & $\begin{array}{l}\text { Gamma/Delta gallery } \\
\text { Mid-sized gallery } \\
\text { National and international client base } \\
\text { Lower price segment to mid-price } \\
\text { segment }\end{array}$ & $\begin{array}{l}\text { Extensive information on website } \\
\text { Web-shop } \\
\text { Active on social media } \\
\text { Online art sales } \\
\text { Changes during pandemic (podcasts, } \\
\text { video tours, live streams on social media) } \\
\text { Spontaneous buyers } \\
\text { Prices and information are transparent }\end{array}$ \\
\hline $\begin{array}{l}\text { Gallery } 9 \\
\text { Art dealer }\end{array}$ & $\begin{array}{l}\text { Beta/Gama gallery } \\
\text { Mid-sized gallery } \\
\text { National client base } \\
\text { Lower price segment to higher price } \\
\text { segment }\end{array}$ & $\begin{array}{l}\text { Extensive information on website } \\
\text { Web-shop } \\
\text { Limited use of social media } \\
\text { Online art sales } \\
\text { Minor changes during pandemic } \\
\text { Long-term relationships with clients and } \\
\text { some spontaneous buyers } \\
\text { Prices and information are transparent }\end{array}$ \\
\hline $\begin{array}{l}\text { Gallery } 10 \\
\text { Art dealer }\end{array}$ & $\begin{array}{l}\text { Beta/Gamma gallery } \\
\text { Small-sized gallery } \\
\text { National client base } \\
\text { Mid-price segment }\end{array}$ & $\begin{array}{l}\text { Extensive information on website } \\
\text { Limited use of social media } \\
\text { Changes during pandemic (3D gallery } \\
\text { views, virtual hanging) } \\
\text { Emphasise the importance of } \\
\text { experiencing art } \\
\text { Long-term relationships with clients } \\
\text { Information is transparent } \\
\text { Prices are intransparent }\end{array}$ \\
\hline $\begin{array}{l}\text { Gallery } 11 \\
\text { Contemporary art gallery }\end{array}$ & $\begin{array}{l}\text { Delta gallery } \\
\text { Small-sized gallery } \\
\text { National and international client base } \\
\text { Lower price segment }\end{array}$ & $\begin{array}{l}\text { Average use of website } \\
\text { Web-shop } \\
\text { Use of social media } \\
\text { Online art sales } \\
\text { Minor changes during pandemic } \\
\text { Waited until restrictions were lifted } \\
\text { Spontaneous buyers } \\
\text { Prices and information are transparent }\end{array}$ \\
\hline $\begin{array}{l}\text { Gallery } 12 \\
\text { Contemporary art gallery }\end{array}$ & $\begin{array}{l}\text { Delta gallery } \\
\text { Small-sized gallery } \\
\text { National and international client base } \\
\text { Lower price segment }\end{array}$ & $\begin{array}{l}\text { Average information on website } \\
\text { Active on social media } \\
\text { Membership on art sales platform (Artsy) } \\
\text { Some online art sales } \\
\text { Minor changes during pandemic (more } \\
\text { information online) } \\
\text { Spontaneous buyers, but also long-term } \\
\text { relationships with clients } \\
\text { Prices and information are transparent }\end{array}$ \\
\hline $\begin{array}{l}\text { Gallery } 13 \\
\text { Contemporary art gallery }\end{array}$ & $\begin{array}{l}\text { Beta/Gamma gallery } \\
\text { Small-sized gallery } \\
\text { National client base } \\
\text { Mid-price segment }\end{array}$ & $\begin{array}{l}\text { Basic information on website } \\
\text { Basic use of social media } \\
\text { No changes during pandemic } \\
\text { Waited until restrictions were lifted } \\
\text { Emphasise the importance of } \\
\text { experiencing art } \\
\text { Long-term relationships whith clients } \\
\text { Prices and information are intransparent }\end{array}$ \\
\hline
\end{tabular}


Table A1. Cont.

\begin{tabular}{|c|c|c|}
\hline Gallery & Gallery Type & Codes/Tags \\
\hline $\begin{array}{l}\text { Gallery } 14 \\
\text { Contemporary art gallery \& art dealer }\end{array}$ & $\begin{array}{l}\text { Beta/Gamma gallery } \\
\text { Mid-sized gallery } \\
\text { National and partly international client } \\
\text { base } \\
\text { Mid- to high price segment }\end{array}$ & $\begin{array}{l}\text { Extensive use of website } \\
\text { Extensive use of social media } \\
\text { Online art sales } \\
\text { Changes during pandemic (exhibition } \\
\text { videos, guided tours) } \\
\text { Mostly long-term relationships with } \\
\text { clients, some spontaneous buyers } \\
\text { Information is transparent } \\
\text { Prices are intransparent }\end{array}$ \\
\hline $\begin{array}{l}\text { Gallery } 15 \\
\text { Contemporary art gallery }\end{array}$ & $\begin{array}{l}\text { Gamma/Delta gallery } \\
\text { Small-sized gallery } \\
\text { National client base } \\
\text { Lower-price segment }\end{array}$ & $\begin{array}{l}\text { Normal use of website } \\
\text { Average use of social media } \\
\text { Minor changes during pandemic (3D } \\
\text { exhibition view) } \\
\text { Personally contacted existing network } \\
\text { during pandemic } \\
\text { Waited until restrictions were lifted } \\
\text { Long-term relationships whith clients } \\
\text { Information is transparent } \\
\text { Prices are intransparent }\end{array}$ \\
\hline
\end{tabular}

\section{Normal use of website}

Delta gallery

Gallery 16

Contemporary art gallery

\section{Gallery 17}

Contemporary art gallery
Small-sized gallery

National client base

Lower-price segment

Prices indicated on website

Limited use of social media

Online art sales

Minor changes during pandemic

(improvements on website)

Spontaneous buyers

Prices and information are transparent

Extensive use of website (new)

Extensive use of social media

Web-shop (for cheaper artworks)

(new)Membership on art sales platforms

Online art sales

Sales inquiries through social media

Alpha/Beta gallery

Mid-sized gallery

National and international client base

Mid- to high price segment
Major changes during pandemic (new website, web-shop, more information online)

Long-term relationships whith clients Prices and information are transparent (new)

Extensive use of website

Extensive use of social media

Online viewing rooms

Online art sales

Alpha gallery

Gallery 18

Contemporary art gallery
Large-sized gallery

International client base

High price segment
Major changes during pandemic (new website, online viewing rooms, live streams, etc.)

Emphasise the importance of experiencing art

Long-term relationships whith clients Information is transparent Prices are intransparent 
Table A1. Cont.

\begin{tabular}{|c|c|c|}
\hline Gallery & Gallery Type & Codes/Tags \\
\hline $\begin{array}{l}\text { Gallery } 19 \\
\text { Contemporary art gallery }\end{array}$ & $\begin{array}{l}\text { Beta/Gamma gallery } \\
\text { Small-sized gallery } \\
\text { National client base } \\
\text { Mid-price segment }\end{array}$ & $\begin{array}{l}\text { Normal use of website } \\
\text { Average use of social media } \\
\text { Minor changes during pandemic (more } \\
\text { information online) } \\
\text { Personally contacted existing network } \\
\text { during pandemicEmphasise the } \\
\text { importance of experiencing art } \\
\text { Long-term relationships whith clients } \\
\text { Prices and information are intransparent }\end{array}$ \\
\hline $\begin{array}{l}\text { Gallery } 20 \\
\text { Contemporary art gallery }\end{array}$ & $\begin{array}{l}\text { Beta gallery } \\
\text { Large-sized gallery } \\
\text { International client base } \\
\text { High price segment }\end{array}$ & $\begin{array}{l}\text { Extensive use of website } \\
\text { Extensive use of social media } \\
\text { Online art sales } \\
\text { Changes during pandemic (exhibition } \\
\text { videos, increased social media activity) } \\
\text { Long-term relationships whith clients } \\
\text { Prices and information are transparent } \\
\text { (new) }\end{array}$ \\
\hline
\end{tabular}

\section{Notes}

1 https:/ / artfacts.net (accessed on 13 July 2021).

2 http://www.artnet.com (accessed on 13 July 2021).

3 https://www.artsy.net (accessed on 13 July 2021).

4 https://www.saatchiart.com (accessed on 13 July 2021).

5 For example, by stating that a famous collector or museum acquired an artwork by a certain artist, the value increases and buyers have more certainty and trust in the quality.

6 Resch's categorisation is based on Robertson (2000) and Thompson (2008) and was found to be the most suitable for this paper. There are other attempts to categorise different types of art galleries, e.g., Bystryn (1978) and Velthuis (2007) for a horizontal categorisation; Adam (2014) and Velthuis (2014) for a vertical categorisation; and Zorloni (2013).

7 However, Arora and Vermeylen (2013) argue that gatekeepers will not be replaced but will become even more important as within this overflow of information people need trustworthy, professional sources to draw on. Moreover, Khaire (2015) argues that discourses by traditional gatekeepers that justify the value of artworks can also be mediated via the Internet.

8 These sources were used to create the list of galleries:1. Google search for art galleries in Vienna and Salzburg.2. http: / / www.wien-kunst.at/galerien/index.html (accessed on 13 July 2021): a long list of numerous contemporary galleries as well as art dealers. The list is not up to date, some galleries no longer exist.3. https:/ / parallelvienna.com/exhibitor-list-2019/ (accessed on 13 July 2021): A list of participants of a contemporary art fair that focuses on young art.4. https://www.viennacontemporary. at/wp-content/uploads/2019/09/vc_2019_AusstellerInnenliste_DE.pdf (accessed on 13 July 2021): A list of attendees of a major contemporary art fair in Vienna.

9 Overall, it should be noted that none of the contacted interview partners-except for two galleries-knew the researcher beforehand.

10 https://atlasti.com (accessed on 13 July 2021).

\section{References}

Adam, Georgina. 2014. Big Bucks: The Explosion of the Art Market in the 21st Century. Farnham: Lund Humphries.

Arora, Payal, and Filip Vermeylen. 2013. Art markets. In Handbook on the Digital Creative Economy. Edited by Ruth Towse and Christian Handke. Cheltenham and Northampton: Edward Elgar Pub, pp. 322-29.

Bayer, Katharina. 2018. Three Essays on Art Ecommerce in the Light of Western Commercial Art Markets. Doctoral dissertation, Technische Universität, Berlin, Germany.

Beckert, Jens, and Jörg Rössel. 2004. Kunst und Preise. KZfSS Kölner Zeitschrift für Soziologie und Sozialpsychologie 56: 32-50. [CrossRef] Bendoly, Elliot, James D. Blocher, Kurt M. Bretthauer, Shanker Krishnan, and M. A. Venkataramanan. 2005. Online/in-store integration and customer retention. Journal of Service Research 7: 313-27. [CrossRef]

Blumenthal, Simone A. 2013. Digitaler Wandel im Kunsthandel. In Bilder der Gegenwart: Aspekte und Perspektiven des Digitalen Wandels. Edited by Harald Klinke and Lars Stamm. Göttingen: Graphentis Verlag, pp. 131-49. 
Bundesministerium für Wissenschaft, Forschung und Wirtschaft/BMWFW. 2017. Mahrer: Kulturangebot ist Zugpferd für Sommertourismus [Press Release]. July 17. Available online: https://www.ots.at/presseaussendung/OTS_20170717_OTS0074/mahrer(accessed on 13 July 2021).

Bourdieu, Pierre. 1993. The Field of Cultural Production: Essays on Art and Literature. Cambridge: Polity Press.

Braun, Virginia, and Victoria Clarke. 2006. Using thematic analysis in psychology. Qualitative Research in Psychology 3: 77-101. [CrossRef]

Bryman, Alan. 2012. Social Research Methods, 4th ed. Oxford: Oxford University Press.

Bystryn, Marcia. 1978. Art galleries as gatekeepers: The case of the abstract expressionists. Social Research 45: 390-408. Available online: https://www.jstor.org/stable/pdf/40970338.pdf (accessed on 13 July 2021).

Caves, Richard Earl. 2000. Creative Industries: Contracts between Art and Commerce. Cambridge: Harvard University Press.

Clarke, Victoria, and Virginia Braun. 2013. Teaching thematic analysis: Overcoming challenges and developing strategies for effective learning. The Psychologist 26: 120-23.

Corbin, Juliet, and Anselm Strauss. 1990. Grounded theory research: Procedures, canons and evaluative criteria. Zeitschrift für Soziologie 19: 418-27. [CrossRef]

Cortimiglia, Marcelo Nogueira, Gregório Ruck Varvaki Rados, and Angela de Moura Ferreira Danilevicz. 2013. Business model innovation: A case study in a value network operator. Paper presented at the 22nd International Conference on Management of Technology, Porto Alegre, Brazil, April 14-18. Available online: https://www.researchgate.net/publication/309563391_ BUSINESS_MODEL_INNOVATION_-_A_CASE_STUDY_IN_A_VALUE_NETWORK_OPERATOR (accessed on 13 July 2021).

de Graaf, Frank Jan, Joost Heinsius, Fred Huibers, Elisabetta Lazzaro, Pawan V. Bhansing, and Alexander Ramselaar. 2019. Capturing Value by Creatives: How to Unite the Cultural and Entrepreneurial Soul. Amsterdam: Hogeschool van Amsterdam. Available online: https: / / catalogus.boekman.nl/pub/P20-0026.pdf (accessed on 13 July 2021).

Dowling, John, and Jeffrey Pfeffer. 1975. Organizational legitimacy: Social values and organizational behavior. Pacific Sociological Review 18: 122-36. [CrossRef]

Ernst \& Young. 2012. The digitisation of everything: How organisations must adapt to changing consumer behaviour. Ernst and Young. Available online: https:/ / www.academia.edu/23705650/The_digitisation_of_everything_How_organisati (accessed on 13 July 2021).

Fassio, Sarah. 2019. The winner takes it all: Die Online-Galerie als Demokratisierungsansatz eines von Intransparenz geprägten Kunstmarktes? In Der Digitale Kulturbetrieb. Edited by Lorenz Pöllmann and Clara Herrmann. Wiesbaden: Springer Gabler, pp. 249-69.

Fillitz, Thomas. 2014. The booming global market of contemporary art. Focaal 69: 84-96. [CrossRef]

Ganesh, Jai. 2004. Managing customer preferences in a multi-channel environment using Web services. International Journal of Retail $\mathcal{E}$ Distribution Management 32: 140-46. [CrossRef]

Gefen, David, Elena Karahanna, and Detmar W. Straub. 2003. Trust and TAM in online shopping: An integrated model. MIS Quarterly 27: 51-90. Available online: http:/ / www.jstor.org/stable/30036519?origin=JSTOR-pdf (accessed on 13 July 2021).

Gerlis, Melanie. 2020. How Covid-19 Has Forced the Art Market's Speedy Digital Conversion. The Art Nerwspaper. May 5. Available online: https: / www.theartnewspaper.com/analysis/how-covid-19-fored-the-art-market-s-speedy-digital-conversion (accessed on 13 July 2021).

Hennigs, Nadine, Klaus-Peter Wiedmann, and Christiane Klarmann. 2012. Luxury brands in the digital age: Exclusivity versus ubiquity. Marketing Review St. Gallen 29: 30-35. [CrossRef]

Janssen, Susanne, and Marc Verboord. 2015. Cultural Mediators and Gatekeepers. In International Encyclopaedia of the Social \& Behavioral Sciences, 2nd ed. Edited by James D. Wright. Oxford: Elsevier, pp. 440-46.

Kassim, Norizan Mohd, and Nor Asiah Abdullah. 2008. Customer loyalty in ecommerce settings: An empirical study. Electronic Markets 18: 275-90. [CrossRef]

Khaire, Mukti. 2015. Art without borders? Online firms and the global art market. In Cosmopolitan Canvases: The Globalization of Markets for Contemporary Art. Edited by Olav Velthuis and Stefano Baia Curioni. Oxford: Oxford University Press, pp. 102-28.

Knebel, Christian. 2007. Anomalies in Fine Art Markets: Three Examples of an Imperfect Market for Perfect Goods. Master's thesis, University of Paderborn, Paderborn, Germany.

Kohle, Hubertus. 2014. Der Kunstmarkt im Internet. In Handbuch Kunstmarkt: Akteure, Management und Vermittlung. Edited by Andrea Hausmann. Bielefeld: Transcript-Verlag, pp. 439-47.

Kumar, Ranjit. 2019. Research Methodology: A Step-by-Step Guide for Beginners, 5th ed. London, Thousand Oaks, New Delhi and Singapore: SAGE Publications.

Kumar, Vipin, and Rajkumar Venkatesan. 2005. Who are the multichannel shoppers and how do they perform? Correlates of multichannel shopping behavior. Journal of Interactive Marketing 19: 44-62. [CrossRef]

Lee, Jin Woo, and Soo Hee Lee. 2019. User participation and valuation in digital art platforms: The case of Saatchi Art. European Journal of Marketing 53. [CrossRef]

Matthews, Robert, and Elizabeth Ross. 2010. Research Methods: A practical Guide for the Social Sciences. Harlow: Pearson.

McAndrew, Clare, ed. 2010. Fine Art and High Finance: Expert Advice on the Economics of Ownership. New York: Bloomberg Press. 
McAndrew, Clare. 2015. TEFAF Art Market Report 2015 [Art Market Report]. The European Fine Art Foundation TEFAF. Available online: http://s3.amazonaws.com/arena-attachments/825953/e29cd8b86dc06b9e864244f220cb1855.pdf?1483758984 (accessed on 13 July 2021).

McAndrew, Clare. 2019. The Art Market 2019: An Art Basel \& UBS Report [Art Market Report]. Art Basel \& UBS. Available online: https:/ / issuu.com/widewalls6/docs/art-market-report-2019 (accessed on 13 July 2021).

McAndrew, Clare. 2021. The Art Market 2021: An Art Basel \& UBS Report [Art Market Report]. Art Basel \& UBS. Available online: https:/ / www.artbasel.com/about/initiatives/theartmarket2021pdf (accessed on 13 July 2021).

Neslin, Scott A., Dhruv Grewal, Robert Leghorn, Venkatesh Shankar, Marije L. Teerling, Jacquelyn S. Thomas, and Peter C. Verhoef. 2006. Challenges and opportunities in multichannel customer management. Journal of Service Research 9: 95-112. [CrossRef]

Piotrowicz, Wojciech, and Richard Cuthbertson. 2014. Introduction to the special issue information technology in retail: Toward omnichannel retailing. International Journal of Electronic Commerce 18: 5-16. [CrossRef]

Polleit-Riechert, Ruth. 2010. Preisentwicklung und Marketing im Zeitgenössischen Kunstmarkt des 21. Jahrhunderts von 2000 bis 2007. Doctoral dissertation, Heinrich-Heine-Universität, Düsseldorf, Germany. Available online: https:/ / docserv.uni-duesseldorf.de/ servlets/DerivateServlet/Derivate-24631/Diss\%20RuthRiechert_24Mar12_9Nov12\%20v5.pdf (accessed on 13 July 2021).

Pownall, Rachel. 2017. TEFAF Art Market Report: Online Focus [Art Market Report]. The European Fine Art Foundation TEFAF. Available online: http:/ / made2measure.org/tefaf/amr2017/ online-art-market (accessed on 13 July 2021).

Resch, Magnus Bruno Frederik. 2011. Management of Art Galleries: Business Models. Doctoral dissertation, University of St. Gallen, St. Gallen, Switzerland. Available online: http://www1.unisg.ch/www/edis.nsf/syslkpbyidentifier/3927/\$file/dis3927.pdf (accessed on 13 July 2021).

Robertson, Iain A. 2000. The Emerging Art Markets of Greater China 1989-1999. Unpublished. doctoral dissertation, City University London, London, UK. Available online: https://openaccess.city.ac.uk/id/eprint/8225/ (accessed on 13 July 2021).

Samdanis, Marios. 2016. The impact of new technology on art. In Art Business Today: 20 Key Topics. Edited by Jos Hackforth-Jones and Iain Robertson. London: Lund Humphries, pp. 164-72.

Schultheis, Franz. 2017. On the price of priceless goods: Sociological observations on and around Art Basel. Journal for Art Market Studies 1: 1-15. [CrossRef]

Sidorova, Elena. 2019. The cyber turn of the contemporary art market. Arts 8: 84. [CrossRef]

Smith, Howard L., Richard Discenza, and Kenneth G. Baker. 2006. Building sustainable success in art galleries: An exploratory study of adaptive strategies. Journal of Small Business Strategy 16: 29-42. Available online: https://libjournals.mtsu.edu/index.php/ jsbs/article/view/44 (accessed on 13 July 2021).

Stone, Merlin, Matt Hobbs, and Mahnaz Khaleeli. 2002. Multichannel customer management: The benefits and challenges. Journal of Database Marketing \& Customer Strategy Management 10: 39-52. [CrossRef]

Teece, David J. 2010. Business models, business strategy and innovation. Long Range Planning 43: 172-94. [CrossRef]

Thompson, Don. 2008. The \$12 Million Stuffed Shark: The Curious Economics of Contemporary Art and Auction Houses. London: Aurum Press.

Throsby, David. 1994. The production and consumption of the arts: A view of cultural economics. Journal of Economic Literature 32: 1-29. Available online: www.jstor.org/stable/2728421 (accessed on 13 July 2021).

Van Miegroet, Hans J., Kaylee P. Alexander, and Fiene Leunissen. 2019. Imperfect data, art markets and internet research. Arts 8: 76. [CrossRef]

Velthuis, Olav. 2007. Talking Prices: Symbolic Meanings of Prices on the Market for Contemporary Art, 4th ed. Princeton and Woodstock: Princeton University Press.

Velthuis, Olav. 2011a. Art dealers. In A Handbook of Cultural Economics, 2nd ed. Edited by Ruth Towse. Cheltenham and Northampton: Edward Elgar Publishing, pp. 28-32.

Velthuis, Olav. 2011b. Art markets. In A Handbook of Cultural Economics, 2nd ed. Edited by Ruth Towse. Cheltenham and Northampton: Edward Elgar Publishing, pp. 33-42.

Velthuis, Olav. 2014. The impact of globalization on the contemporary art market: The traditional gallery model at risk. In Risk and Uncertainty in the Art World. Edited by Anna M. Dempster. London: Bloomsbury, pp. 87-108.

Verhoef, Peter C., Pallassana K. Kannan, and Jeffrey J. Inman. 2015. From multi-channel retailing to omni-channel retailing: Introduction to the special issue on multi-channel retailing. Journal of Retailing 91: 174-81. [CrossRef]

Yogev, Tamar. 2009. The social construction of quality: Status dynamics in the market for contemporary art. Socio-Economic Review 8: 511-36. [CrossRef]

Zorloni, Alessia. 2013. The Economics of Contemporary art: Markets, Strategies, and Stardom. Berlin/Heidelberg: Springer. 